\title{
Investigation of the Horizontal Track Geometry regarding Geogrid Reinforcement under Ballast
}

\author{
Szabolcs Fischer \\ Széchenyi István University \\ Egyetem tér 1, H-9026 Győr, Hungary \\ fischersz@sze.hu
}

\begin{abstract}
This paper was written concerning a test section with geogrid-reinforced railway ballast based on field tests. I aim to introduce the variation of the alignment track geometry parameter taking into consideration the geogrid reinforcement. The main advantage of the ballast reinforcement with geosynthetic inclusions is the reduction of the longitudinal level faults and the deterioration speed. I observed the alignment (i.e., the horizontal geometry) changes. The duration of the field test is approximately 11.5 years. Five different geogrid types were incorporated below the ballast bed on the Kelenföld-Hegyeshalom state board (No. 1) railway line in Hungary in 2010. The test section is only straight for $700 \mathrm{~m}$ in length (with reference sections with the same geometry and structural set-up), i.e., the horizontal geometry of the track does not influence the results. A statistical analysis was executed to compare the behavior of the sections, based on both the geogrid-reinforced sections and reference sections. As a result of the investigation, it can be concluded that there were some geogrid types, which seemed to be adequate to decrease the deterioration speed of the alignment parameter of the ballasted railway track. A very high variance (standard deviation) was observed in the results, this is because they cannot be determined as a general horizontal railway track stabilizing solution.
\end{abstract}

Keywords: geogrid reinforcement; railway; geometrical stabilization; ballast; alignment

\section{Introduction}

Railway transportation is one of the most environment-friendly solutions in the world because it chiefly uses electric hauling. The prevailing superstructure type is the ballasted track; the ballastless track set-up is mainly related to high-speed railways, bridges, tunnels, trams, and subways [1]. The railway cross-section of ballasted railways contains super- and substructure. Primarily, the superstructure is loaded by the highest forces from the railway vehicles. The most considerable inner forces arise in the rails, however, the ballast bed's top surface receives approximately $300-400 \mathrm{kPa}$ normal (vertical stresses); while the subgrade is loaded by $100 \mathrm{kPa}$ [2]. The high stresses can result in significant plastic vertical 
deformation in the sub- and super-structures, which leads to frequent geometrical correction.

A lot of literature are concerned with the rails [3-6]. Some researchers publish about rail wear process in straight and sections with horizontal curves [3]; the rail's and wheel's corrugations, and the changed bearing capacity due to rail wear [4]. Kuchak et al. [5] analyzed rail dampers using finite element method (FEM). Kazemian et al. [6] assessed the condition monitoring of vibration of ballasted tracks in Iran based on rail problems. The fragmentation and breakage of the ballast particles connects to the environment protection because of the frequent ballast screening process, as well as the dust pollution. Benmebarek and Movahedi [7] dealt with the discrete element modeling of fragmental granular materials; hence Sysyn et al. [8] performed laboratory experiments searching the accurate relationship between interlocking effect and the testes materials, as well as the applied loading condition. Ballast interlocking is a relevant field regarding the deterioration of the ballasted track that is able to be improved by geosynthetic layers.

If someone considers the accurate geodesy and comprehensive integrated infrastructure related to railways, the papers of Kampczyk and Dybel [9], and Matejov and Sestakova [10] can be referred.

This paper is about geosynthetic reinforcement that can stabilize the track geometry of ballasted tracks. Geosynthetic reinforcement is a well-known solution for soil stabilization. The geosynthetic inclusions provide additional shear and tensile strength to the soils. It has to be mentioned that the geosynthetic reinforcement is adequate for soils, and the granular media, too [11-13].

Incorporating geogrid layer under ballast can improve the track structure's inner shear resistance and load-bearing capacity [14]. However, the interaction behavior between ballast aggregates and geosynthetic is not yet fully known.

The author started his research in this area in 2008. In 2010, a test section was built using five geosynthetic types, adequate for railway geometry stabilization; thus, 11.5 years have elapsed since then. The author assembled the measurement data recorded by railway track geometry measuring car. In this paper, he analyzed the alignment parameter in this test section, i.e., the effect of geogridreinforcement under the ballast bed on changing the horizontal geometry of the ballasted railway track. It is not evident whether the geogrid layer stabilizes the alignment or not. The general goal of the paper is not to declare which geosynthetic product is the best or more valuable than the others. The geogrids' original name and product type have not been used; only anonym designations (GG1 to GG5).

The author submitted a paper in Geotextiles and Geomembranes journal, in which he analyzed the vertical track geometry [15]. This current paper deals with only the horizontal geometry, i.e., the alignment railway track geometry parameter. 


\section{Methods}

\subsection{Methods for Calculation}

A railway test section was configured on the No. 1 railway line in Hungary (see Fig. 1).

LÉBÉNY-MOSONSZENTMIKLÓS

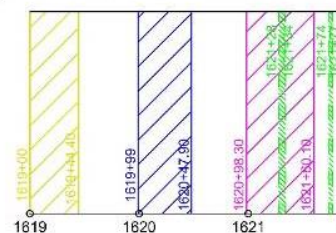

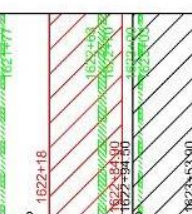

1622
HEGYESHALOM

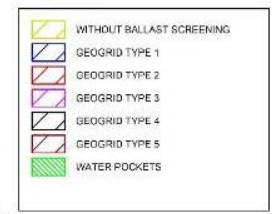

Figure 1

Locations of subsections at the test site (the internal white zones are the WG subsections; WBS: without ballast screening, WG: without geogrid))

The field tests are related to measuring, calculating, determining, and evaluating railway track geometry changes. The author details the performed measurements as below:

i) Geometric (geodetic) leveling in the time interval 2010 and 2014

ii) Railway track geometry measurements in the time interval 2010 and 2021

In i), the distance of measuring points was $1.8 \mathrm{~m}$. The following parameters were determined by calculation: i) cross-level (height difference between rail heads; i.e., similar to the superelevation parameter but not only in the curve); ii) longitudinal level (i.e., the settlement; based on different chord lengths); iii) twist (i.e., the plane distortion; based on different base lengths); iv) settlement values on individual sleepers.

The author applied and dealt only with the above ii) measurements and their data processing, evaluation.

The effective field (railway track geometry) measurements were carried out using the FMK-007 type recording car of MÁV CRTI Ltd. (Central Rail and Track Inspection Ltd.) [16]. The dynamic (related to vehicle) measurements were not considered in this paper. The author summarized the measurable and countable parameters of the recording car [16]:
i) Track gauge (unit: $\mathrm{mm}$ )
ii) Cross-level (unit $\mathrm{mm}$ )
iii) Twist on five different bases (units: $\mathrm{mm} / \mathrm{m}$ or $\mathrm{mm} / \mathrm{mm}$ ) 
iv) Longitudinal level on original or on any chord, and in D1 or D2 wavelength range (unit: $\mathrm{mm}$ )

v) Alignment on original or on any chord, and in D1 or D2 wavelength range (unit: $\mathrm{mm}$ )

vi) Gauge-changing on any base (unit: $\mathrm{mm} / \mathrm{m}$ or $\mathrm{mm} / \mathrm{mm}$ )

vii) Average-gauge on any base (unit: $\mathrm{mm}$ )

viii) Curvature (unit: $1 / \mathrm{m}$ or $1 / \mathrm{mm}$ )

ix) Twist-differences on 5 different bases (unit: $\mathrm{mm} / \mathrm{m}$ or $\mathrm{mm} / \mathrm{mm}$ )

$\mathrm{x}$ Longitudinal level moving standard deviation on any base (unit: $\mathrm{mm}$ )

Statistical methodologies were applied for the calculations and assessments of the test sections: regression analysis was executed to be able to compare the deterioration of the different subsections. Linear regression functions and approximation for the deterioration of railway track geometry were used, Nagy and Horvat [17] published and certified that this approximation is adequate for straight sections up to 10 years.

The author decided to analyze in this paper only the alignment, one of the railway track geometry parameters. In the international literature, no one has certified and published whether how the geogrid reinforcement under ballast bed influences the alignment of the railway track; in straights or in curves, as seen in Eq. (1):

$$
I R \_C L=I R_{\text {left }}+I R_{\text {right }}
$$

where IR is the measuring value related to alignment parameter calculated by area method (unit: $\mathrm{dm}^{2}$ ); CL: characteristic length, based on Hungarian railway diagnostics practice [18], is $200 \mathrm{~m}$; in this paper, $10 \mathrm{~m}$ length value was taken into consideration); $\mathrm{IR}_{\text {left }}$ and $\mathrm{IR}_{\text {right }}$ : alignment measuring values (or numbers) for the left and right rails using area method, respectively (unit: $\mathrm{dm}^{2}$ );

It has to be noted that the alignment parameter was determined with the measured data per $25 \mathrm{~cm}$; ensuring the FMK-007 recording car. The IR measuring numbers was considered as chord-basis measurement, not the D1 (i.e., chord-torsion-free) assessment. The author considered only the alignment 'IR_10 m' parameter. Measurements by FMK-007 recording car: there were 34 measurement dates between 30.08.2010 and 27.07.2021.

\subsection{Applied Geosynthetic Types and Their Properties}

The type of installed geogrids are detailed in Tables 1, 2, 3, and Fig. 2. Fig. 2 contains the meaning of the abbreviations in Table 1, while MD means machine direction, XMD means cross-machine direction. 


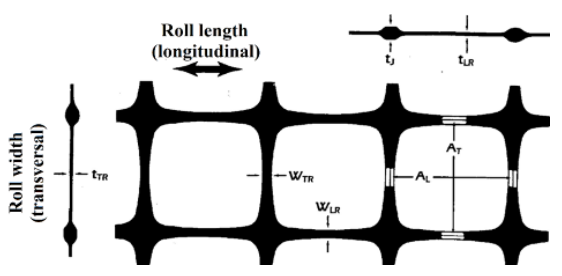

Figure 2

Meanings of geometrical characteristics of installed geogrids

Table 1

The characteristics of installed geogrids 1

\begin{tabular}{|c|c|c|c|c|c|c|c|c|c|c|c|}
\hline $\begin{array}{c}\text { Geogrid } \\
\text { types }\end{array}$ & $\begin{array}{c}\text { Base } \\
\text { mate- } \\
\text { rial }\end{array}$ & $\begin{array}{c}\text { Prod. } \\
\text { techn. }\end{array}$ & $\begin{array}{c}\text { Uniaxial/ } \\
\text { biaxial }\end{array}$ & $\begin{array}{c}\mathrm{A}_{\mathrm{L}} \\
{[\mathrm{mm}]}\end{array}$ & $\begin{array}{c}\mathrm{A}_{\mathrm{T}} \\
{[\mathrm{mm}]}\end{array}$ & $\begin{array}{c}\mathrm{W}_{\mathrm{LR}} \\
{[\mathrm{mm}]}\end{array}$ & $\begin{array}{c}\mathrm{W}_{\mathrm{TR}} \\
{[\mathrm{mm}]}\end{array}$ & $\begin{array}{c}\mathrm{t}_{\mathrm{J}} \\
{[\mathrm{mm}]}\end{array}$ & $\begin{array}{c}\mathrm{t}_{\mathrm{LR}} \\
{[\mathrm{mm}]}\end{array}$ & $\begin{array}{c}\mathrm{t}_{\mathrm{TR}} \\
{[\mathrm{mm}]}\end{array}$ \\
\hline \multirow{2}{*}{$\mathrm{GG} 1$} & $\mathrm{PP}^{4}$ & extruded & biaxial & 65.0 & 65.0 & 4.0 & 4.0 & 7.0 & 1.7 & 1.5 \\
\cline { 2 - 12 } $\mathrm{GG}$ & $\mathrm{PP}^{4}$ & extruded & biaxial & 65.0 & 65.0 & 4.0 & 4.0 & 7.0 & 1.7 & 1.5 \\
\cline { 2 - 11 } $\mathrm{GG}^{1}$ & $\mathrm{PP}^{4}$ & extruded & biaxial & 65.0 & 65.0 & 4.0 & 4.0 & 7.0 & 2.5 & 1.5 \\
\cline { 2 - 11 } $\mathrm{GG}^{2}$ & $\mathrm{PP}^{4}$ & welded & biaxial & 80.0 & 80.0 & 8.8 & 8.2 & 2.1 & 1.4 & 1.4 \\
\cline { 2 - 12 } $\mathrm{GG}^{3}$ & $\mathrm{PP}^{4}$ & welded & biaxial & 80.0 & 80.0 & 8.8 & 8.2 & 2.1 & 1.4 & 1.4 \\
\hline
\end{tabular}

${ }^{1}:$ it is the same as Geogrid type 1, but factory combined with geotextile

2: factory-made geocomposite; i.e., the geotextile is between the ribs

${ }^{3}$ : it is the same as GG4 but manually combined with geotextile under geogrid

3: polypropylene

Table 2

The characteristics of installed geogrids 2

\begin{tabular}{|c|l|l|l|l|l|l|}
\hline $\begin{array}{c}\text { Geogrid } \\
\text { types }\end{array}$ & \multicolumn{2}{|c|}{$\begin{array}{c}\text { Ultimate tensile } \\
\text { strength }\end{array}$} & \multicolumn{2}{c|}{$\begin{array}{c}\text { Tensile strength } \\
\text { at } 2 \% \text { elongation }\end{array}$} & \multicolumn{2}{|c|}{$\begin{array}{c}\text { Elongation at } \\
\text { max. strength }\end{array}$} \\
\cline { 2 - 7 } & $\begin{array}{c}\mathrm{MD} \\
{[\mathrm{kN} / \mathrm{m}]}\end{array}$ & $\begin{array}{c}\text { XMD } \\
{[\mathrm{kN} / \mathrm{m}]}\end{array}$ & $\begin{array}{c}\mathrm{MD} \\
{[\mathrm{kN} / \mathrm{m}]}\end{array}$ & $\begin{array}{c}\text { XMD } \\
{[\mathrm{kN} / \mathrm{m}]}\end{array}$ & $\begin{array}{c}\text { MD } \\
{[\mathrm{kN} / \mathrm{m}]}\end{array}$ & $\begin{array}{c}\text { XMD } \\
{[\mathrm{kN} / \mathrm{m}]}\end{array}$ \\
\hline \multirow{2}{*}{ GG1 } & 30 & 30 & 11 & 12 & N.A. & N.A. \\
\cline { 2 - 7 } GG2 & 30 & 30 & 11 & 12 & N.A. & N.A. \\
GG3 $^{1}$ & 26.3 & 28 & 10 & 9 & N.A. & N.A. \\
GG4 $^{2}$ & 30 & 30 & 12 & 12 & N.A. & N.A. \\
GG5 $^{3}$ & 30 & 30 & 12 & 12 & N.A. & N.A. \\
\cline { 2 - 8 }
\end{tabular}

Table 3

The characteristics of installed geogrids 3

\begin{tabular}{|c|c|c|c|c|c|c|c|c|c|}
\hline \multirow{2}{*}{$\begin{array}{l}\text { Geotextile } \\
\text { in the } \\
\text { geo- } \\
\text { composite }\end{array}$} & \multirow[t]{2}{*}{$\begin{array}{l}\text { Puncture } \\
\text { force }[\mathrm{N}]\end{array}$} & \multicolumn{2}{|c|}{ Tensile strength } & \multicolumn{2}{|c|}{$\begin{array}{c}\text { Elongation at max. } \\
\text { strength }\end{array}$} & \multirow{2}{*}{$\begin{array}{c}\text { Water } \\
\text { perme- } \\
\text { ability } \\
{[\mathrm{m} / \mathrm{s}]}\end{array}$} & \multirow{2}{*}{$\begin{array}{c}\text { Water } \\
\text { perme- } \\
\text { ability } \\
{\left[\ell / \mathrm{sm}^{2}\right]}\end{array}$} & \multirow{2}{*}{$\begin{array}{c}\text { Mass } \\
\text { per unit } \\
{\left[\mathrm{kg} / \mathrm{m}^{2}\right]}\end{array}$} & \multirow{2}{*}{$\begin{array}{c}\text { Charac- } \\
\text { teristic } \\
\text { opening } \\
\text { size } \\
{[\mathrm{mm}]}\end{array}$} \\
\hline & & $\begin{array}{c}\mathrm{MD} \\
{[\mathrm{kN} / \mathrm{m}]}\end{array}$ & $\begin{array}{c}\mathrm{XMD} \\
{[\mathrm{kN} / \mathrm{m}]}\end{array}$ & $\begin{array}{c}\mathrm{MD} \\
{[\mathrm{kN} / \mathrm{m}]}\end{array}$ & $\begin{array}{c}\text { XMD } \\
{[\mathrm{kN} / \mathrm{m}]}\end{array}$ & & & & \\
\hline GG2 & $>1500$ & N.A. & N.A. & N.A. & N.A. & 0.135 & 135 & 0.160 & 0.125 \\
\hline GG4 & 1670 & 6 & 11 & 60 & 40 & 0.110 & 110 & 0.150 & 0.130 \\
\hline $\mathrm{GG}^{3}$ & 1670 & 6 & 11 & 60 & 40 & 0.110 & 110 & 0.150 & 0.130 \\
\hline
\end{tabular}




\section{Field Tests}

In Table 4, the author gives the details of the parameters related to all the subsections.

Table 3

The characteristics of installed geogrids 3

\begin{tabular}{|c|c|}
\hline sectioning & $\begin{array}{l}1619+00 \ldots 1626+00(\text { these are hectometer section formats; i.e., } \\
1619+00 \text { means } 161.9 \mathrm{~km})\end{array}$ \\
\hline $\begin{array}{l}\text { right or left track of the } \\
\text { railway line; straight or } \\
\text { curve(d) section; type of } \\
\text { railway embankment (fill } \\
\text { or cut) }\end{array}$ & right; straight; fill \\
\hline longitudinal slope & $+0.64 \mathrm{~mm} / \mathrm{m}$ according to the sectioning \\
\hline $\begin{array}{l}\text { allowed speed and axle } \\
\text { load; type of superstructure }\end{array}$ & $\mathrm{V}=160 \mathrm{~km} / \mathrm{h} ; \mathrm{Q}=225 \mathrm{kN} ;$ ballasted CWR track \\
\hline $\begin{array}{l}\text { rail profiles and rail } \\
\text { fasteners }\end{array}$ & $\begin{array}{l}54 \text { E1 (i.e. UIC 54) rail profiles, rolled in Diósgyőr (Hungary) } \\
\text { in 1980; Vossloh Sk1 } 3 \text { type flexible rail fasteners }\end{array}$ \\
\hline sleepers and sleeper space & LM 80 type reinforced-concrete sleepers; $60 \mathrm{~cm}$ sleeper spaces \\
\hline $\begin{array}{l}\text { ballast type; effective } \\
\text { ballast depth }\end{array}$ & $\begin{array}{l}31.5 / 50 \mathrm{~mm} \text { A or B according to EN } 13450: 2002 \text { standard [19]; } \\
\text { effective ballast depth: } 41 \ldots 54 \mathrm{~cm} \text { (based on the field } \\
\text { measurements in 2010) }\end{array}$ \\
\hline dewatering problem & $\begin{array}{l}\text { there is a dirt road on the right side of the permanent way, its } \\
\text { level is relatively high, and the precipitation was hardly able to } \\
\text { run off/flow away from the track. This problem was partially } \\
\text { solved in } 2011 \text { and } 2014 \text {; location of water pockets: see Fig. } 1\end{array}$ \\
\hline $\begin{array}{l}\text { the type of installed } \\
\text { geogrids and their location }\end{array}$ & see Tables 1,2 , and 3 , as well as Fig. 1 \\
\hline $\begin{array}{l}\text { geotechnical parameters of } \\
\text { the site }\end{array}$ & see Fig. 1, and Tables 5 and 6 \\
\hline
\end{tabular}

The author collected the geotechnical parameters and characteristics of the sections with water pockets in April 2010 in Tables 5 and 6, before the geogrid installation. The $\mathrm{E}_{2}$ load bearing capacity values are according to the Hungarian standard [20], and they are measured with static load plate test.

Table 5

The characteristics of subgrade soils in/under water pockets 1

\begin{tabular}{|c|c|c|c|c|}
\hline \multirow{2}{*}{ Characteristics } & \multicolumn{4}{|c|}{ Sectioning } \\
\cline { 2 - 5 } & $1620+50$ & $1621+29$ & $1621+70$ & $1622+58$ \\
\hline Soil name & silt & lean clay & silt & lean clay \\
\hline Water content: w [\%] & $22.4 / 22.5$ & $20.9 / 20.0$ & $20.9 / 25.5$ & $21.6 / 23.1$ \\
\hline Liquid limit: wL $_{\text {[\%] }}$ & 33.6 & 35.5 & 33.9 & 35.8 \\
\hline Plasticity index: IP (\%) & 13.3 & 15.2 & 14.1 & 15.4 \\
\hline
\end{tabular}




\begin{tabular}{|c|c|c|c|c|}
\hline Void ratio: e [-] & 0.65 & 0.60 & 0.61 & 0.61 \\
\hline Relative saturation: $\mathrm{S}_{\mathrm{r}}$ & 0.93 & 0.94 & 0.93 & 0.96 \\
\hline $\begin{array}{c}\text { Compressibility (bulk) } \\
\text { modulus: } \mathrm{E}_{\mathrm{s}} \text { (MPa) }\end{array}$ & 3.7 & 3.7 & 3.1 & 3.2 \\
\hline $\begin{array}{c}\text { Load bearing capacity } \\
\text { (with static plate test): } \mathrm{E}_{2} \\
\text { (MPa) }\end{array}$ & 13.6 & 19.6 & 16.9 & 15.2 \\
\hline
\end{tabular}

Table 6

The characteristics of subgrade soils in/under water pockets 2

\begin{tabular}{|c|c|c|c|c|}
\hline \multirow{2}{*}{ Characteristics } & \multicolumn{4}{|c|}{ Sectioning } \\
\cline { 2 - 5 } & $1623+05$ & $1624+00$ & $1624+95$ & $1625+50$ \\
\hline Soil name & silt & silt & silt & silt \\
\hline Water content: w [\%] & $22.4 / 20.8$ & $19.4 / 21.1$ & $20.8 / 18.5$ & $20.7 / 20.8$ \\
\hline Liquid limit: wL [\%] & 34.5 & 31.0 & 32.6 & 37.9 \\
\hline Plasticity index: IP (\%) & 12.8 & 12.4 & 13.3 & 13.9 \\
\hline Void ratio: e [-] & 0.65 & 0.57 & 0.57 & 0.61 \\
\hline Relative saturation: $\mathrm{S}_{\mathrm{r}}$ & 0.93 & 0.93 & 0.98 & 0.92 \\
\hline $\begin{array}{c}\text { Compressibility (bulk) } \\
\text { modulus: } \text { Es }_{\text {s }} \text { MPa) }\end{array}$ & 2.8 & 2.6 & 3.6 & 3.0 \\
\hline $\begin{array}{c}\text { Load bearing capacity } \\
\text { (with static plate test): } \mathrm{E}_{2}\end{array}$ & 15.1 & 19.6 & 18.6 & 21.1 \\
(MPa) & & & & \\
\hline
\end{tabular}

The author chose this $700 \mathrm{~m}$ long section for his analysis due to the continuous intensive deterioration between 1999 and 2010. A ballast cleaning was planned in 2010 to repair the sections with water pockets. This work was supplemented with the geogrids' installation on nights of May 25/26 and 26/27, 2010. It has to be noted that during the ballast cleaning, there was a little rain, the contamination remained in the ballast bed due to the wet ballast particles, i.e., the work can't provide the best result.

Four different deterioration phases were considered. The author collected the elapsed days and the cumulated million gross tons, which were calculated from the last correction tamping after the geogrids' installation (June 16, 2010; 0 MGT). The Hungarian State Railway (MÁV) supplied the data below.

- $\quad$ Deterioration phase \#9: between 25.11.2013 (Day 1257; 25.966 MGT) and 03.08.2014 (Day 1508; 37.703 MGT)

- Deterioration phase \#10: between 25.11.2014 (Day 1622; 44.058 MGT) and 25.04.2016 (Day 2139; 65.707 MGT)

- Deterioration phase \#11: between 15.08.2016 (Day 2251; 70.151 MGT) and 09.08.2019 (Day 3340; 115.194 MGT)

- $\quad$ Deterioration phase \#12: between 09.12.2019 (Day 3462; 420.402 MGT) and 27.07.2021 (Day 4058; 145.132 MGT) 
The dates of the tamping processes can be seen in Fig. 3 .

It has to be mentioned that the geometrical deterioration of the railway track is mainly influenced by the tamping process (manually or machine). It has to be taken into consideration. Because of that, deterioration phases \#1 to \#8 were neglected in the calculations due to their relatively short phases.

\section{Results and Discussion}

The author gave his results in Figs. 3-4. The abbreviations and vertical dashed lines in the figures have the following meanings:

- GG1...GG5: sections established with GG1...GG5 type geogrids under ballast bed

- the eleven vertical dashed black lines in the figures show the date of tamping processes between June 17, 2010, and July 27, 2021 (see Chapter 3)

Figs. 3-4 contain the graphs related to variation compared to the WG subsection's behavior. Therefore, it is the only adequate basis to compare the different subsections regarding the reinforcement effect, i.e., the effect on the variation of the alignment (track geometry) parameter.

The average (A) and the standard deviation (SD) values were computed based on all the subsections (see Fig. 1), the shorter subsections (i.e., WG) were considered altogether in a common section. The relative standard deviation (RSD) values can be determined based on the ratio of SD and A; it is not calculated from the whole data series, only the estimated two numbers: standard deviation and average.

Fig. 4 has the only results related to those whose $R^{2}$ value was higher than 0.7 (mainly higher than 0.8 , but some were taken into consideration with $\mathrm{R}^{2}=0.7 \ldots 0.8$ coefficient values).

Fig. 3 d)-f), and Fig. 4 are worth analyzing in detailed manner. Based on the results of Figs. 3 d)-f), it can be concluded that the ratio of the different subsections had varying behaviors considering the alignment (track geometry) parameter. $0.6 \ldots 1.3 ; 0.2 \ldots 2.5 ; 0.5 \ldots 1.3$ ranges can be seen, in case of VorA, VorSD, and VorRSD, respectively. The meanings of these abbreviations can be found in the title of Fig. 3. 

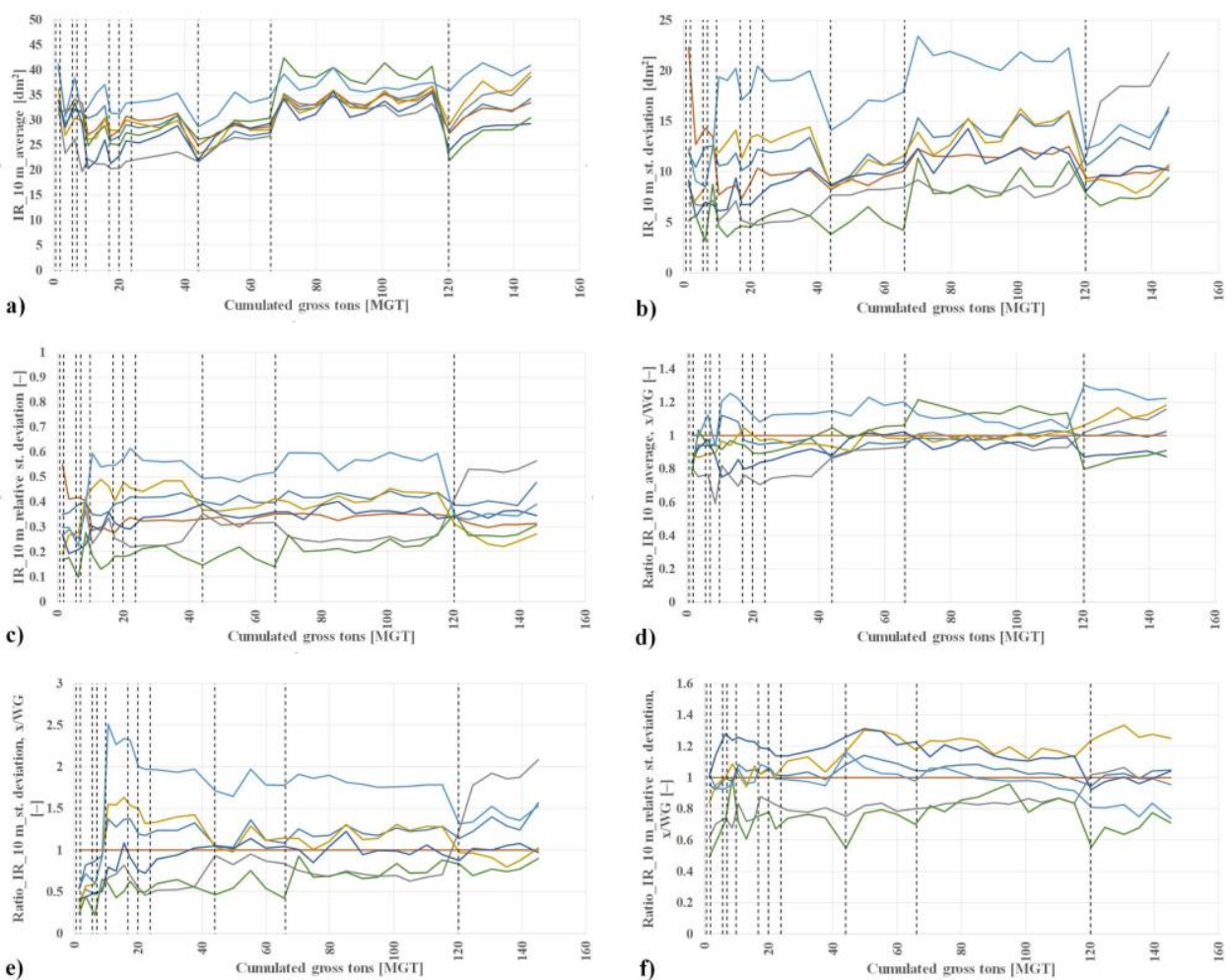

$$
\text { -WBS -WG -GG1 -GG2 -GG3 -GG4 -GG5 }
$$

Figure 3

a) Variation of IR_10 m_average (VoA) parameter; b) Variation of IR_10 m_standard deviation (VoSD) parameter; c) Variation of IR_10 m_relative standard deviation (VoRSD) parameter; d) Variation of the ratio of IR_10 m_average (VorA) values calculated for the different subsections to the average values calculated for the WG subsection; e) Variation of the ratio of IR_10 m_standard deviation (VorSD) values calculated for the different subsections to the average values calculated for the WG subsection; f) Variation of the ratio of IR_10 m_relative standard deviation (VorRSD) values calculated for the different subsections to the average values calculated for the WG subsection
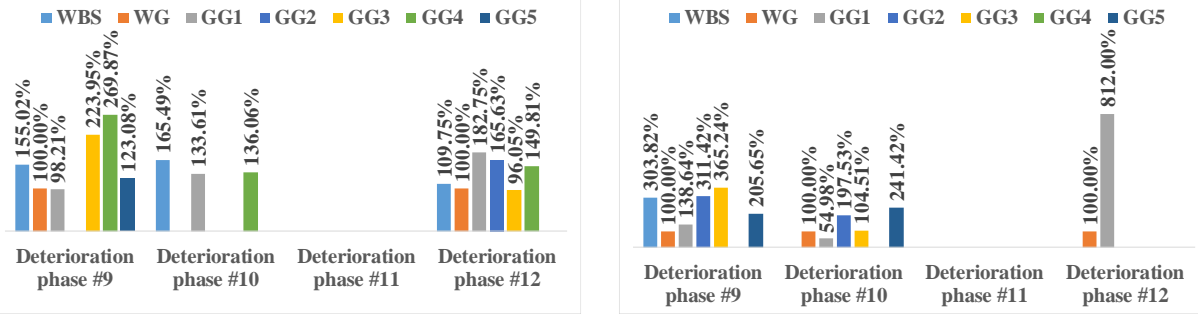


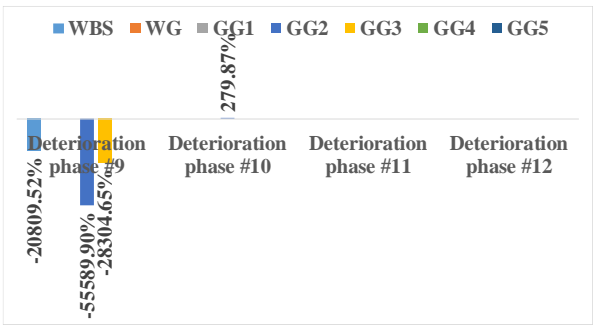

Figure 4

Above left: Deterioration speed values of IR_10 m_average related to the deterioration phases \#9 to \#12 compared to the deterioration speed of subsection WG; Above right: Deterioration speed values of IR_10 m_standard deviation related to the deterioration phases \#9 to \#12) compared to the deterioration speed of subsection WG; Bottom: Deterioration speed values of IR_10 m_relative standard deviation related to the deterioration phases \#9 to \#12 compared to the deterioration speed of subsection WG

First, the author can state that in Fig. 4, the above right and bottom charts show useless information, so the deterioration speed of SD and RSD functions can't be applied to assess the changing alignment track geometry parameter. The missing columns indicate that the correlations are inadequate, and they have to be neglected in the evaluation.

Based on Fig. 3, it can be concluded that the line WG show a general deterioration rate (see Fig. 3a); variation of average values of alignment). It means that the comparison can be appropriate. There are only very few types of geogrids (see Fig. 3 d)-f)) which provided better behavior than the WG subsection. If all the A, SD and RSD are considered, only the GG4 subsection can ensure reinforcement, i.e., lower ratios than the subsection WG. It is a very interesting result that GG5 shows poor achievement (even up to 1.30 ratio) in case of A and SD (Fig. $3 \mathrm{~d}$ ) and e)), but in the case of RSD (Fig. $3 \mathrm{f}$ )) its result seems to be one of the best (even lower than $0.80 \ldots 0.75$ ). GG3 can also be mentioned regarding the A (see Fig. 3, a)) as a potential adequate reinforcing solution.

If someone analyzes and assesses Fig. 4, the above-left chart in the deterioration phase \#12, only the GG3 subsection is able to be noted (with 96.05\%) as an appropriate one. The other sub-charts and deterioration phases don't contain consequent results, which can be adequate for correct evaluation. The highest value $(182.75 \%)$ is connected to the GG1 subsection. It is extraordinary because GG1 type geogrid ensured one of the best reinforcement effects in vertical geometry [15].

The results show a very high variance (standard deviation); in this way, the author cannot state that the geogrid reinforcement unequivocally helps in stabilizing the horizontal geometry of the ballasted railway track. 


\section{Conclusions}

I summarized my experiences, concerning the changing of alignment track geometry parameters, on a test site in Hungary, where five different types of geosynthetic layers were applied under the ballast bed. These geosyntetic inclusions were installed in the right track of No. 1 MÁV railway line in May 2010, since then, 11.5 years have elapsed. I presented my results in another paper related to the vertical track geometry [15], however, the work herein is about the stabilization of the horizontal geometry. FMK-007 type track geometry, recording car's measurements, can be applied for the statistical time-series analysis, to compare the sections with each other and with the reference sections (subsection WG - without geogrid reinforcement).

The International Literature is not conclusive and it is not evident that geosynthetic reinforcements under the ballast bed, in the railway superstructures, can or cannot stabilize, the horizontal track geometry. I have shown that the GG3 and GG4 geogrid types seem to be adequate. The GG3 was able to decrease the deterioration speed of the railway track geometry, regarding alignment (IR) parameter; hence, the GG4 geogrid type ensured a significantly low value, in the case of VorA, VorSD and VorRSD.

The results show a very high variance (Standard Deviation); in this way, I cannot state that the geogrid reinforcement unequivocally helps in stabilizing the horizontal geometry of the ballasted railway track.

My future plans are to continue my research related to this test site. The future measurement data can be the basis of additional and more detailed assessments.

\section{Acknowledgement}

The author acknowledges the help and support of MÁV, as well as MÁV CRTI Ltd. In addition, the author has much to be thankful for Prof. Ferenc Horvát, his quondam Ph.D. supervisor.

At MÁV the following people helped the most (the list doesn't contain every person): I. Virág, D. Szekeres, B. Suhajda, I. Sándor, B. Kókai, A. Mátrai-Ortelli, K. Szokolai, D. Kovács-Balázs, G. Hegedüs, S. Kiss, T. Boda, I. Sári, K. Ráczné Szabó, T. Szalai.

\section{References}

[1] V. Jover, L. Gaspar, S. Fischer, Investigation of Geometrical Deterioration of Tramway Tracks. Nauka ta Progres Transportu, Vol. 86, No. 2, 2020, pp. 46-59

[2] A. Németh, S. Fischer, Investigation of glued insulated rail joints applied to CWR tracks. Facta Universitatis-Series Mechanical Engineering, 2021, 7642 
[3] M. Kurhan, D. Kurhan, R. Novik, S. Baydak, N. Hmelevska, Improvement of the railway track efficiency by minimizing the rail wear in curves. IOP Conference Series: Materials Science and Engineering, Vol. 985, No. 1, 2020, 012001

[4] V. Kovalchuk, M. Sysyn, Y. Hnativ, A. Onyshchenko, M. Koval, O. Tiutkin, M. Parneta, Restoration of the Bearing Capacity of Damaged Transport Constructions Made of Corrugated Metal Structures. Baltic Journal of Road and Bridge Engineering, Vol. 16, No. 2, 2021, pp. 90-109

[5] A. J. Tigh Kuchak, D. Marinkovic, M. Zehn, Finite element model updating - Case study of a rail damper. Structural Engineering and Mechanics, Vol. 73, No. 1, 2020, pp. 27-35

[6] M. Kazemian, F. Astaraki, M. R. Movahedi, A. Taheri, Condition monitoring of vibration at weak parts of rail for ballasted railway tracks in Iran. Journal of the Korean Society for Railway, Vol. 24, No. 6, 2021, pp. 544-551

[7] A. Benmebarek, M. R. Movahedi, DEM modeling of crushable grain material under different loading conditions. Periodica Polytechnica Civil Engineering, Vol. 65, No. 3, 2021, pp. 935-945

[8] M. Sysyn, O. Nabochenko, V. Kovalchuk, M. Przybyłowicz, S. Fischer, Investigation of interlocking effect of crushed stone ballast during dynamic loading. Reports in Mechanical Engineering, Vol. 2, No. 1, 2021, pp. 65-76

[9] A. Kampczyk, K. Dybeł, Integrating surveying railway special grid pins with terrestrial laser scanning targets for monitoring rail transport infrastructure. Measurement: Journal of the International Measurement Confederation, Vol. 170, 2021, 108729

[10] A. Matejov, J. Šestáková, The Experiences with utilization of BIM in railway infrastructure in Slovak Republic and Czech Republic. Transportation Research Procedia, Vol. 55, 2021, pp. 1139-1146

[11] Q. Gu, K. Shi, X. Bian, S. He, Behavior of Geogrid-Reinforced Railway Ballast under Train Traffic Loads. Lecture Notes in Civil Engineering, Vol. 165, 2022, pp. 689-701

[12] S. F. Ibrahim Alabdullah, A. J. Kadhim, H. B. Khalaf, Life Cycle Cost Analysis for Reinforced Geogrid Railway Track. International Journal of GEOMATE, Vol. 19, No. 75, 2020, pp. 191-196

[13] Y. Jiang, S. Nimbalkar, Finite element modeling of ballasted rail track capturing effects of geosynthetic inclusions. Frontiers in Built Environment, Vol. 5, 2019, 69

[14] S. Fischer, Investigation of Inner Shear Resistance of Geogrids Built Under Granular Protection Layers and Railway Ballast. Nauka ta Progres Transportu, Vol. 59, No. 5, 2015, pp. 97-106 
[15] S. Fischer, Geogrid reinforcement of ballasted railway superstructure for stabilization of the railway track geometry - A case study. Geotextiles and Geomembranes, 2021, submitted manuscript

[16] MÁV CRTI Ltd., Track diagnostics - FMK-007 track measuring wagon. http://mavkfv.hu/index.php?f=vaganydiagnosztika_fmk007 [online, last visited on: 2021.10.04]

[17] R. Nagy, F. Horvat, Indirect determination of the measurement accuracy of the FMK-004 track geometry measuring carr used on Hungarian rail network. The $16^{\text {th }}$ International Conference Computational Civil Engineering 2021, IOP Conference Series: Materials Science and Engineering, 2021, 10 p.

[18] Hungarian State Railways, D.54, Construction and track maintenance technical data, regulations. 1988

[19] MSZ EN 13450:2003: Aggregates for railway ballast, $33 \mathrm{p}$.

[20] MSZ 2509-3:1989, Bearing capacity test on pavement structures. Plate bearing test., $6 \mathrm{p}$. 